\title{
SIKAP MASYARAKAT DI DESA BATU BUSUK, SUMATERA BARAT TERHADAP KONSERVASI HARIMAU SUMATERA (PANTHERA TIGRIS SUMATRAE) BERDASARKAN PENGETAHUANNYA
}

\author{
Ade Suryanda, Ratna Komala, dan Suci Rahmawati \\ Pendidikan Biologi, FMIPA, Universitas Negeri Jakarta \\ E-mail: adesuryanda@yahoo.com.
}

\begin{abstract}
Sumatran tiger are one of the potential biodiversity populations which continue to decline. One of the few causes of this can occur because of human activities and actions unfavorable to the environment. Therefore, people need to have an attitude of conservation of Sumatran tiger. One of the factors that influence the attitude is knowledge. The study aims to determine the correlation between knowledge with the attitude of the Sumatran tiger conservation. The research was conducted in the village of Batu busuk, West Sumatra in May 2016. The method used was survey method with correlational studies. Data was normally distributed and homogeneous. The simple regression equation is $\hat{Y}=110,936+0.414 X$. Correlation coefficient obtained is 0,14 which means that there is a correlation between knowledge and towards Sumatran tiger conservation. Knowledge of Sumatran tiger conservation accounted for $1,92 \%$ of the behavior towards Sumatran tiger conservation. The result of this study concluded that there was positive correlation between knowledge and attitude of Sumatran tiger conservation.
\end{abstract}

Kata kunci: Attitude, Batu busuk village, conservation, knowledge, Sumatran tiger.

\section{PENDAHULUAN}

Perkiraan populasi harimau sumatera sekitar 250 individu berdasarkan data Soehartono, et al. (2007). Sedikitnya jumlah populasi harimau sumatera tersebut disebabkan oleh berkurangnya hewan mangsa. Berkurangnya jumlah hewan mangsa harimau sumatera ini disebabkan berkurangnya luasan habitat karena alih fungs habitat. Hal ini dapat berdampak pada kelangsungan hidup harimau sumatera.

Ketika sumber makanan dan tempat berlindung sudah mulai terbatas, maka harimau sumatera akan mencari lokasi alternatif untuk berburu mangsa. Lokasi yang ideal adlah dengan mendatangi permukiman masyarakat. Kehadiran harimau sumatera ini akan menimbulkan konflik dengan masyarakat. Seringnya konflik terjadi antara manusia dan harimau sumatera, memicu sikap masyarakat yang negatif terhadap harimau sumatera. Sikap negatif terhadap harimau sumatera juga dapat ditimbulkan karena rendahnya pengetahuan (Kubiatko, 2012).

Notoadmodjo (2007), mendefinisikan pengetahuan sebagai hasil penginderaan manusia, atau hasil tahu seseorang terhadap obyek melalui indera yang dimilikinya (mata, hidung, telinga, dan sebagainya). Sedangkan sikap dapat diartikan sebagai suatu hal yang menentukan sifat, hakikat, baik perbuatan sekarang maupun perbuatan yang akan datang 
(Ahmadi, 2007). Dalam hal ini berarti sikap masyarakat Desa Batu Busuk, Sumatera Barat ditentukan oleh pengetahuan yang dimiliki oleh masyarakat.

Pengetahuan tentang konservasi harimau sumatera diperlukan dalam menciptakan sikap positif terhadap konservasi harimau sumatera. Hubungan antara pengetahuan dan sikap terhadap konsevasi harimau sumatera perlu untuk diteliti. Hal ini bertujuan untuk melihat seberapa besar dukungan pengetahuan yang dimiliki masyarakat dapat membentuk sikap yang positif dan mendukung terhadap konservasi harimau sumatera.

\section{METODE PENELITIAN}

Penelitian ini menggunakan metode penelitian deskriptif dengan teknik survey dan studi korelasional.. Variabel bebas dalam penelitian ini adalah pengetahuan mengenai konservasi harimau sumatera, variabel terikatnya adalah sikap terhadap konservasi harimau sumatera. Penelitian dilakukan pada bulan Maret-Mei tahun 2016.

Populasi target dalam penelitian ini adalah seluruh masyarakt Desa Batu Busuk, Kecamatan Pauh, Sumatera Barat. Populasi terjangkau meliputi seluruh kepala keluarga yang ada di Desa Batu busuk, Kecamatan Pauh, Sumatera Barat. Sampel pada penelitian ialah kepala keluarga di Desa Batu busuk, Kecamatan Pauh, Sumatera Barat. Bedasarkan rumus Isaac dan Michael didapatkan 100 orang sampel dari 140 kepala keluarga di Desa Batu Busuk dan diambil secara Simple Random Sampling

\section{HASIL DAN PEMBAHASAN}

Perbandingan persentase kategori skor pengetahuan tentang konservasi harimau sumatera terlihat pada Gambar 1.

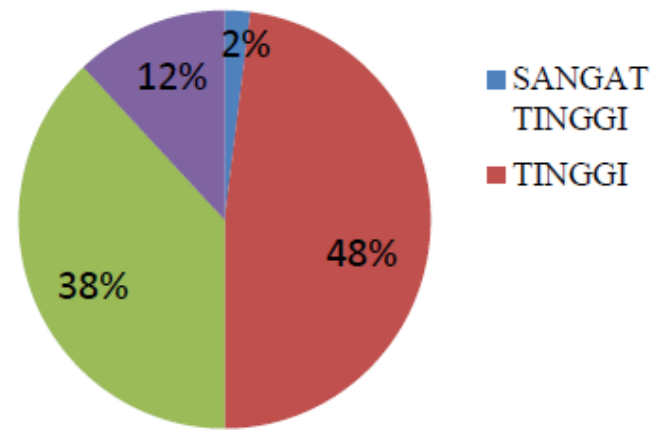

Gambar 1. Persentase Kategori Skor Pengetahuan Konservasi Harimau Sumatera

Distribusi frekuensi skor pengetahuan mengenai konservasi harimau sumatera dapat dilihat pada Gambar 2. 


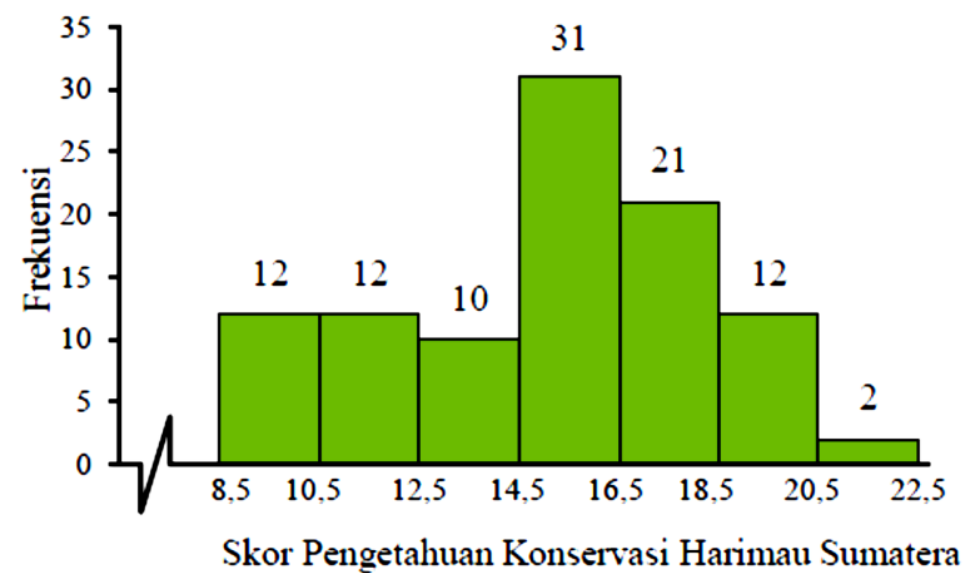

Gambar 2. Distribusi frekuensi skor pengetahuan konservasi harimau sumatera

Perbandingan persentase skor dimensi pengetahuan yang terdiri atas dimensi faktual, konseptual, prosedural dan metakognitif dapat dilihat pada Gambar 3.

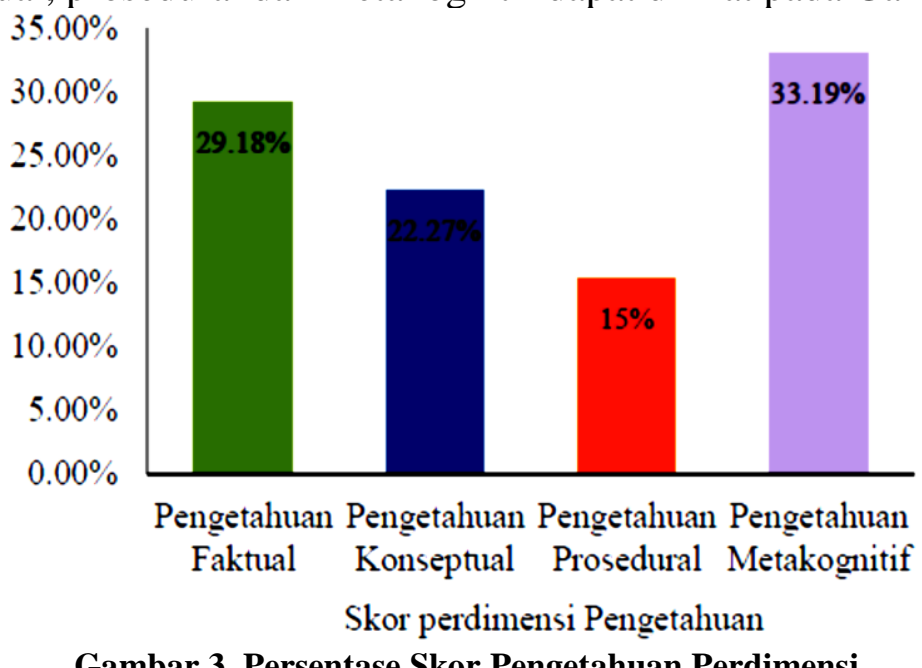

Perbandingan persentase kategori skor sikap masyarakat terhadap konservasi harimau sumatera terlihat pada Gambar 4

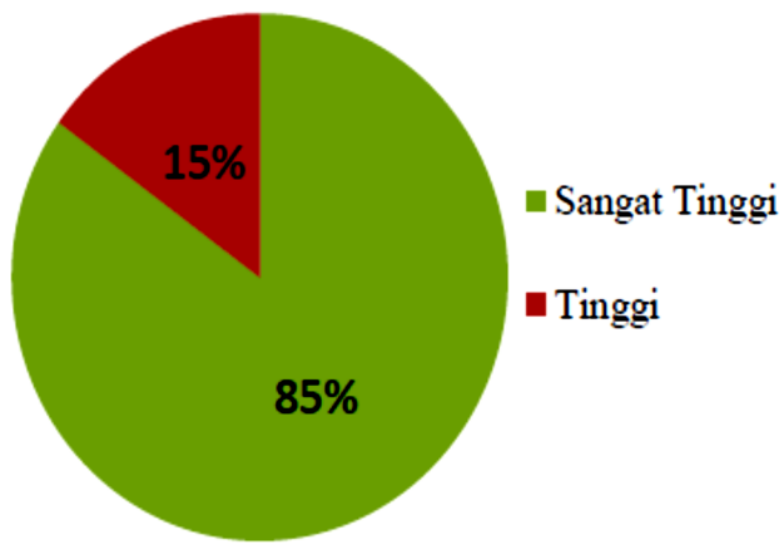

. Gambar 4. Persentase Kategori Skor Sikap terhadap Konservasi Harimau Sumatera 
Distribusi frekuensi skor sikap masyarakat terhadap konservasi harimau sumatera dapat dilihat pada Gambar 5.

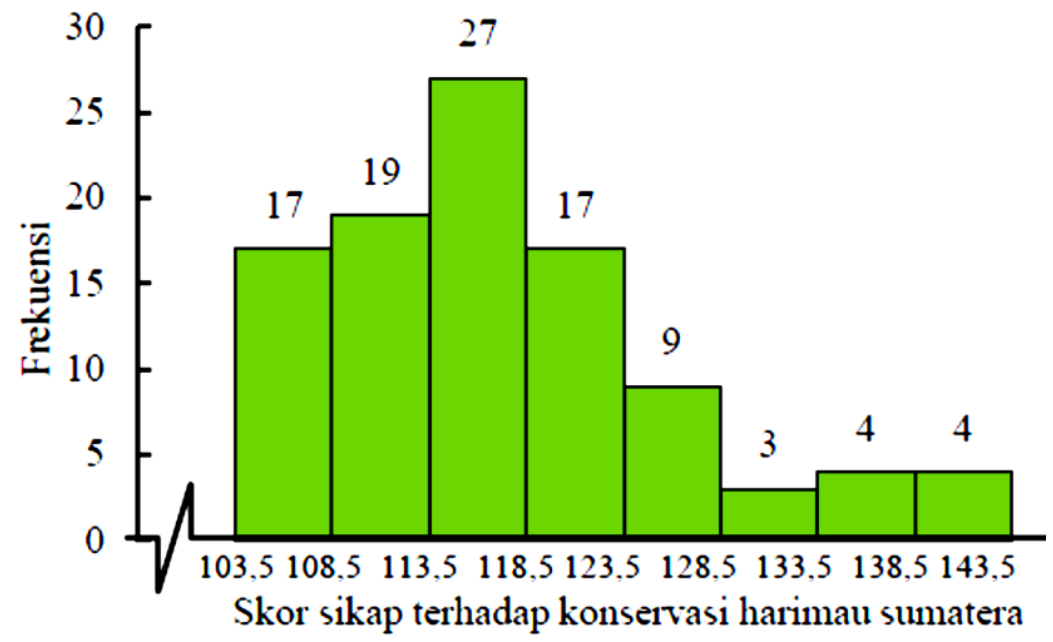

Gambar 5. Distribusi Frekuensi Skor Sikap Terhadap Konservasi Harimau Sumatera

Perbandingan persentase skor dimensi sikap yang terdiri atas dimensi Naturalistic, Ecologistic, Scientistic dan Negativistic dapat dilihat pada Gambar 6.

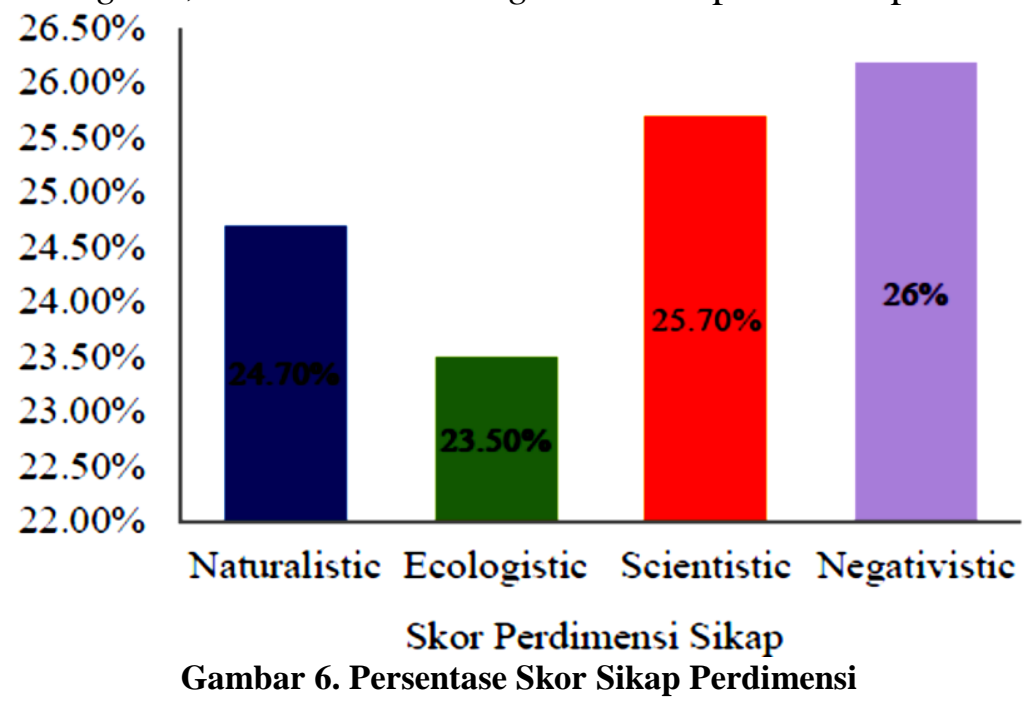

Berikut model regresi skor pengetahuan dengan sikap terhadap konservasi harimau sumatera. 


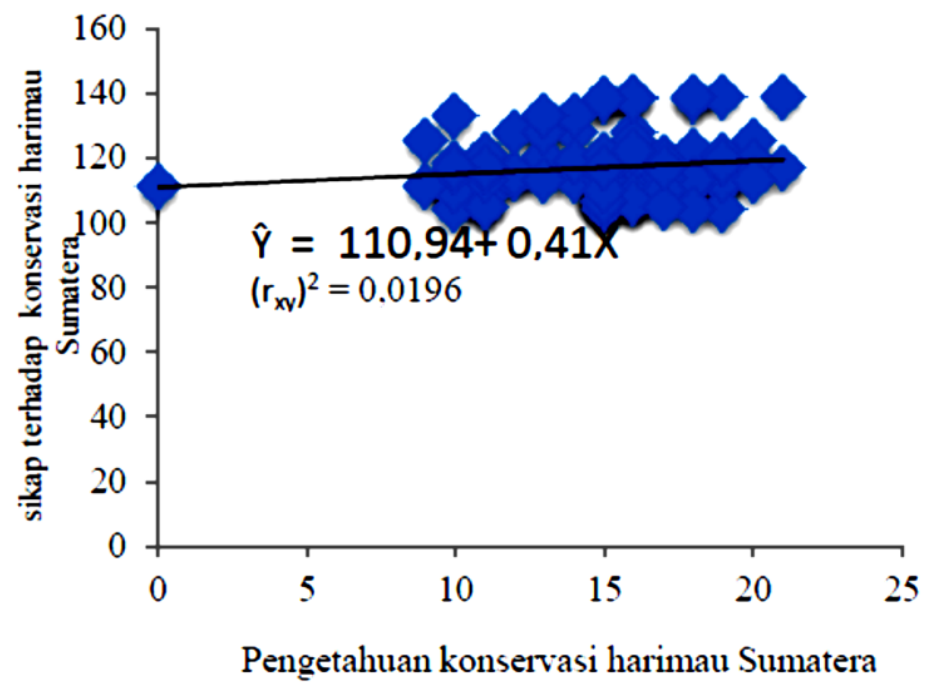

Gambar 7. Model Regresi Linear antara skor pengetahuan urban farming dengan partisipasi pengembangan vertical farming.

Berdasarkan hasil penelitian mengenai pengetahuan masyarakat Desa Batu Busuk tentang konservasi harimau Sumatera diperoleh bahwa tidak ada masyarakat yang memiliki pengetahuan rendah. Menurut rata-rata skor pengetahuan, didapati bahwa pengetahuan masyarakat tergolong baik (Arikunto, 2013). Sukmadinata (2007) menyatakan bahwa beberapa faktor eksternal yang mempengaruhi pengetahuan seseorang antara lain yaitu tingkat pendidikan dan ekonomi (pekerjaan). Masyarakat Desa Batu Busuk dengan pendidikan terakhir Perguruan Tinggi memiliki rata-rata skor pengetahuan yang lebih tinggi dibanding dengan masyarakat dengan pendidikan terakhir SMA, SMP dan SD. Tingkat pendidikan merupakan salah satu faktor yang membentuk pengetahuan seseorang, semakin tinggi pendidikan seseorang maka akan memberikan respon yang lebih rasional terhadap informasi yang datang Notoatmodjo (2003).

Faktor lain yang membentuk pengetahuan seseorang yakni faktor ekonomi yang didasarkan atas pekerjaan. Sukmadinata (2007) menyatakan bahwa seseorang dengan status ekonomi tinggi lebih mudah mencukupi kebutuhan primer dan kebutuhan sekunder dibandingkan dengan seseorang dengan status ekonomi rendah, dimana kebutuhan akan informasi yang termasuk kebutuhan sekunder. Hal ini sesuai dengan apa yang didapatkan pada penelitian bahwa masyarakat yang bekerja sebagai wiraswasta memiliki rata-rata skor tertinggi dibanding dengan masyarakat yang bekerja sebagai petani maupun buruh. Dengan status ekonomi yang tinggi ini memberi peluang untuk memenuhi kebutuhan sekundernya, diantaranya adalah kebutuhan akan informasi.

Berdasarkan dimensi pengetahuan Anderson dan Krathwohl (2001) maka dimensi pengetahuan metakognitif mendapatkan persentase skor tertinggi dari keempat dimensi pengetahuan. Dimensi pengetahuan metakognitif mencakup pengetahuan strategi, pengetahuan kognitif, konstektual, dan kondisional serta pengetahuan tentang diri. Dimensi ini mencakup pengetahuan tentang strategi dimana seseorang dituntut untuk berpikir dan memecahkan suatu masalah berdasarkan dengan pengetahuan yang dimiliki.

Pengetahuan metakognitif yang tinggi seharusnya diikuti pula oleh pengetahuan faktual, konseptual serta prosedural yang juga tinggi. Crose dan Jacobs dalam Desoete (2001) menjelaskan bahwa pengetahuan metakognitif berkaitan dengan ketiga tipe pengetahuan yaitu: pengetahuan deklaratif, pengetahuan prosedural dan pengetahuan kondisional dalam pembelajaran. Dimana Pengetahuan deklaratif mengacu kepada 
pengetahuan tentang fakta dan konsep-konsep yang dimiliki seseorang. Pengetahuan prosedural adalah pengetahuan bagaimana melakukan langkah-langkah atau strategi dalam suatu proses pemecahan masalah. Pengetahuan kondisional mengacu pada kesadaran seseorang akan kondisi yang mempengaruhi dirinya dalam memecahkan masalah.

Pengetahuan metakognitif yang tinggi pada masyarakat diduga disebabkan karena masyarakat memiliki pengalaman mengenai bagaimana cara memecahkan suatu masalah yang berkaitan dengan konservasi harimau Sumatera. Gamma dalam Mulbar (2009) menyatakan bahwa, pengetahuan metakognitif adalah pengetahuan yang dimiliki seseorang dan tersimpan di dalam memori jangka panjang, berarti pengetahuan tersebut dapat diaktifkan atau dipanggil kembali sebagai hasil dari suatu pencarian memori yang dilakukan secara sadar dan disengaja, atau diaktifkan tanpa sengaja/ secara otomatis muncul ketika seseorang dihadapkan pada permasalahan tertentu.

Persentase skor terendah pada dimensi pengetahuan didapati oleh dimensi pengetahuan prosedural. Dimensi pengetahuan prosedural ialah dimensi yang mencakup tentang keahlian khusus serta pengetahuan tentang metode dan teknik khusus untuk mengerjakan sesuatu. Bethany, et al., (2015) dalam penelitiannya menunjukkan bahwa, pengetahuan prosedural dipengaruhi oleh pengetahuan konseptual. Hal ini sesuai dengan hasil yang diperoleh bahwa dimensi pengetahuan konseptual memperoleh persentase skor yang cukup rendah. Pengetahuan prosedural yang rendah juga diduga disebabkan oleh kesulitan masyarakat dalam mengurutkan langkah-langkah atau urutan prosedural dalam menangani masalah konservasi harimau sumatera secara tepat.

Sikap masyarakat terhadap konservasi harimau sumatera menurut rata-rata skor tergolong kepada kategori baik (Arikunto, 2013). Sebagaimana telah dijelaskan, bahwa dengan sikap yang baik berarti masyarakat bersikap positif terhadap harimau sumatera juga mendukung konservasi harimau sumatera. Azwar (2007) mengungkapkan bahwa salah satu faktor yang dapat membentuk sikap seseorang ialah pendidikan.

Pendidikan yang tinggi berarti memiliki pengetahuan yang lebih luas sehingga segala macam sikap yang dibentuk akan berdasarkan pada pengetahuan yang dimiliki. Sikap yang dibentuk juga berlandaskan atas pemahaman akan baik buruk, garis pemisah antara sesuatu yang boleh dan yang tidak boleh dilakukan dan semua itu diperoleh dari pendidikan (Azwar, 2013). Faktor lain yang juga membentuk sikap seseorang ialah pekerjaan. Bambang (2008) menyatakan bahwa pekerjaan yang dilakukan secara terus menerus akan membentuk pengalaman bagi masyarakat dan akan menjadi pemahaman tentang bagaimana cara bersikap terhadap sesuatu. Menurut teori, apabila tidak memiliki pengalaman terhadap suatu objek maka akan cenderung menolak dan bersikap negatif terhadap objek tersebut.

Serpell dalam Prokop (2008) menyatakan bahwa terdapat 9 sikap manusia terhadap hewan, dimana 4 diantaranya memiliki kedekatan antara masing-masing dimensi yaitu Naturalistic, Ecologistic, Scientistic dan Negativistic. Dimensi sikap yang mendapatkan persentase skor tertinggi ialah dimensi Negativistic. Dimensi Negativistic menurut Serpell (2004) ialah sikap menghindari hewan secara aktif atau pasif karena ketidakpedulian, kebencian dan ketakutan. Hal ini menjelaskan bahwa sikap masyarakat terhadap konservasi harimau sumatera yang tergolong baik lebih banyak karena masyarakat merasa takut dan cenderung akan menghindari konflik dengan harimau sumatera. Hasil wawancara dengan masyarakat mengenai pendapat masyarakat tentang harimau Sumatera, hampir seluruh masyarakat menjawab bahwa masyarakat 
mempercayai bahwa harimau sumatera adalah hewan yang sakral dan patut untuk dihormati.

Dimensi sikap yang mendapatkan skor terendah ialah dimensi Ecologistic. Dimensi sikap Ecologistic mencakup perhatian utama pada lingkungan sebagai kesatuan yang menghubungkan antara hewan liar dengan habitat alaminya. Hasil wawancara menunjukkan bahwa masyarakat Desa Batu Busuk sebagian besar masih belum memahami bahwa hutan sangatlah penting sebagai habitat alami harimau sumatera. Masyarakat berasumsi bahwa hutan di wilayah Sumatera masih luas dan cukup untuk hidup harimau sumatera. Masyarakat juga mengungkapkan bahwa apabila pada kawasan hutan konservasi di buka untuk lahan perkebunan maka tidaklah mempengaruhi kehidupan harimau sumatera.

Masyarakat Desa Batu Busuk selain kurang memahami apa fungsi hutan bagi harimau sumatera, masyarakat juga kurang memahami bahwa keberadaan hewan mangsa harimau sumatera memiliki peran yang sangat esensial dalam menjaga harimau sumatera dari kepunahan. Hasil wawancara menyebutkan bahwa, meskipun masyarakat Desa Batu Busuk sedikit yang melakukan perburuan terhadap hewan mangsa harimau sumatera, namun ternyata banyak pemburu yang datang dari luar Desa Batu Busuk. Tetapi mirisnya, masyarakat kurang peduli terhadap hal tersebut.

Dimensi sikap Scientistic dan Naturalistic masing-masing mendapatkan skor sebesar $25.67 \%$ dan 24.68\%. Serpell (2004) menjelaskan bahwa dimensi sikap Scientistic ialah sikap yang terbentuk karena memiliki perhatian utama pada bentuk fisik hewan, fungsi biologis dan keingintahuan terhadap hewan. Masyarakat mengetahui ada beberapa orang di luar Desa Batu Busuk yang memakai bagian-bagian tubuh harimau Sumatera untuk keperluan pribadi seperti taring harimau yang dipakai untuk praktik perdukunan atau kulit harimau yang digunakan untuk pajangan di rumah. Namun masyarakat menyatakan bahwa tidak pernah memiliki taring harimau sumatera ataupun kulit harimau sumatera meskipun memiliki nilai yang sangat tinggi. Sedangkan dimensi sikap Naturalistic yaitu sikap yang muncul karena meminati dan peduli pada hewan liar dan alam bebas. Dimensi sikap Naturalistic yang dimiliki masyarakat didasarkan dari sikap masyarakat yang mempercayai bahwa harimau Sumatera adalah penjaga keselamatan hidup mereka, sehingga kepedulian masyarakat akan kelestarian harimau Sumatera mendorong masyarakat bersikap positif terhadap konservasi harimau Sumatera.

Hubungan antara pengetahuan konservasi harimau sumatera dengan sikap masyarakat terhadap konservasi harimau sumatera memiliki hubungan yang positif namun memiliki nilai koefisien korelasi sangat rendah yakni hanya sebesar 0,14 . Hal ini diduga karena selain pengetahuan dalam aspek konservasi, pengetahuan kearifan lokal masyarakat Desa Batu Busuk juga turut berkontribusi lebih dalam membentuk sikap masyarakat terhadap konservasi harimau sumatera.

Koefisien determinasi menyatakan bahwa pengetahuan konservasi harimau sumatera memberikan kontribusi terhadap sikap konservasi harimau Sumatera hanya sebesar 1,96\%. Hal ini berarti bahwa 98,04\% terdapat faktor lain yang menentukan sikap seseorang diantaranya pengalaman pribadi, kebudayaan, orang lain yang dianggap penting, media massa, institusi atau lembaga pendidikan dan lembaga agama, serta faktor emosi dalam diri individu.

Berdasarkan hasil penelitian, faktor lain yang menentukan sikap selain pendidikan serta pekerjaan kemungkinan besar ialah kebudayaan yang dimiliki masyarakat serta pengalaman pribadi yang dialami oleh masyarakat. Salah satu faktor yang menentukan bagaimana sikap manusia terhadap hewan ialah kepentingan budaya dan sejarah yang 
dimiliki oleh hewan tersebut. Hal ini sesuai dengan penelitian Kartika (2013) yang menjelaskan bahwa sikap masyarakat Sumatera Barat terhadap harimau sumatera lebih banyak dibentuk oleh kearifan lokal dimana masyarakat sangat menghormati harimau sumatera bahkan masyarakat memberikan julukan tertinggi sebagai "inyak" kepada harimau sumatera. Tarrant et al. (1997) menemukan bahwa pengetahuan tidak secara langsung membentuk sikap masyarakat terhadap konservasi, tetapi pengetahuan menjadi variabel mediasi eksternal untuk membentuk sikap masyarakat terhadap konservasi.

\section{KESIMPULAN}

Berdasarkan hasil penelitian maka dapat disimpulkan bahwa terdapat hubungan positif antara pengetahuan dengan sikap masyarakat terhadap konservasi harimau Sumatera. Hubungan ini termasuk kriteria yang cukup rendah.

\section{DAFTAR PUSTAKA}

Ahmadi, A. (2007). Psikologi Sosial. Rineka Cipta, Jakarta.

Anderson, L.W., \& Krathwohl, D.R. (2001). A Taxonomy for Learning, Teaching, and Assesing; A revision of Bloom's Taxonomy of Education Objectives. Addison Wesley Lonman Inc., New York.

Arikunto, S. (2013). Prosedur Penelitian Suatu Pendekatan Praktek Rineka Cipta, Yogyakarta

Azwar, S. (2013). Sikap Manusia Teori dan Pengukurannya. Pustaka Pelajar. Yogyakarta .

Bambang, W. (2008). Teknologi Pembelajaran, Landasan dan Aplikasinya. Rineka Cipta. Jakarta.

Bethany R-Johnson \& Michael, S \& John R. Star. (2015). Not a One-Way Street: Bidirectional Relations Between Procedural and Conceptual Knowledge of Mathematics. Educational Psychology Review DOI 10.1007/s10648-015-9302-x. Springer, New York. December 2015, Volume 27, Issue 4, pp 587-597

Desoete, A. (2001). Off-line metacognition in children with mathematics learning disabilities. Unpublished doctoral research. Ghent: RUG University, Belgium.

Kartika, E.C. (2013). Understanding Key Determinants And Human Dimensions Of Human Tiger Conflict In West Sumatra Indonesia. Thesis MSc. Wageningen University.

Kubiatko, M. (2012). Lower Secondary Scholl Pupils Knowledge and Attitudes Toward Animals. International Journal of Biology Education; 2 (2).

Mulbar, U. (2009). Pembelajaran Matematika Realistik yang Melibatkan Metakognisi Siswa di Sekolah Menengah Pertama. Disertasi tidak dipuiblikasikan. UNESA, Surabaya. 
Notoatmodjo, S. (2007). Promosi Kesehatan dan Ilmu Perilaku. Jakarta: Rineka Cipta

Prokop, P., \& M. Kubiatko. (2008). Bad wolf kills lovable rabbits: children's attitudes toward predator and prey. Electronic Journal of Science Education, 12; 55-70.

Serpell, J. A. (2004). Factor Influencing Human Attitude to animals and Their Welfare. Animal Welfare. 13: 145-151

Soehartono, T., Hariyo T. Wibisono, Sunarto, Deborah Martyr, Herry Djoko Susilo, Thomas Maddox, \& Dolly Priatna. (2007). Strategi dan rencana aksi konservasi harimau sumatera (Panthera tigris sumatrae) 2007-2017. Departemen Kehutanan, Jakarta.

Sukmadinata, S. N. (2007). Metode Penelitian Pendidikan. Remaja Rosdakarya, Bandung.

Suhartono. (2005). Pengembangan Keterampilan Bicara Anak Usia Dini. Jakarta: Depdiknas.

Tarrant, M.A., A.D. Bright., H. Ken Cordell. (1997). Attitudes toward wildlife species protection: Assesing moderating and mediating effects in value attitude relationship. Human Dimension of Wildlife 2, 1-20.

Wibisono, H. T. and Pusarini, W. (2010). Sumatran tiger (Panthera tigris sumatrae): A review of conservation status. Integrative Zoology 5 (4):31323 